\title{
Koloproktológia régen és ma a Semmelweis Egyetem I. sz. Sebészeti Klinikáján
}

\author{
ZARÁND ATTILA, BENCZE VIKTÓRIA, DÁNIEL ÁDÁM, FERREIRA GÁBOR, MIHELLER PÁL, \\ ÓNODY PÉTER, WELTNER JÁNOS, ZSIRKA-KLEIN ATTILA, SZIJÁRTÓ ATTILA
}

Semmelweis Egyetem, I. sz. Sebészeti Klinika, Budapest

\begin{abstract}
A kolorektális karcinóma a férfiak esetében a harmadik, nők esetében a második leggyakoribb rákos megbetegedés a világon. 2018-ban megközelítőleg 1,8 millió új esetet igazoltak világszerte. Becslések szerint Magyarországon évente 7500-8000 új megbetegedéssel kell számolni. A vastagbélrák miatti halálozás Európában az elmúlt két évtizedben csökkent, különösen a nők körében. A tendenciák azonban országonként és korcsoportonként eltérőek. Az Európai Unióban 1997 és 2007 között a vastagbélrák okozta mortalitás évente mintegy 2\%-kal csökkent. A tartósan kedvező tendenciákat Nyugat- és Észak-Európa országaiban figyelték meg, míg a kelet-európai országok számos országában, például a Cseh Köztársaságban, Magyarországon és Szlovákiában a közelmúltban ismét romló adatokat észleltek, különösen a nők esetében. A kolorektális halálozási arány közelmúltbeli csökkenése számos európai országban valószínűleg a (korai) diagnózis és kezelés javulásának köszönhetö, ennek következtében magasabb a túlélés is. ${ }^{1}$ A vastagbélrák terheinek további csökkentését célzó intézkedések (pl. vastagbél szürés) azonban továbbra is indokoltak, különösen a kelet-európai országokban.
\end{abstract}

\section{Kolorektális sebészet \\ az I. sz. Sebészeti Klinikán}

1826-ban Jacques Lisfranc végezte el az első sikeres gát felőli végbél eltávolítást, perineális kolosztóma képzéssel. Ezt követően, 1885-ben Kocher, majd 1886-ban Kraske az os coccygeum eltávolításával végzett sikeres rektum reszekciót, megtartva a végbél záróizmát. A mütéti technikák és a narkózis fejlődésével megteremtödött a kiterjedtebb mütétek elvégzésének lehetősége. 1908-ban Sir Ernest Miles (Czerny 1884-ben közölt technikáját továbbfejlesztve) publikálta az abdominoperineális rektumexstirpáció módszerét. Henri Hartmann 1921-ben végezte el az első anterior/has felőli végbélrezekciót a disztális végbél helybenhagyásával, kolosztóma képzéssel. Ez a mütéti típus kevesebb intraoperatív vérvesztéssel járt és a posztoperatív halálozás lényegesen kisebb volt Miles módszeréhez képest. Claude Dixon 1948-ban publikálta a záróizom megörzését biztosító anterior rektumreszekció technikáját, mely során primer anasztomózist is varrt. Ez azóta is a végbélsebészet alap mütéti technikájának számít. A végbélrák kezelésének fontos mérföldköve volt az ép circumferenciális rezekciós felszín jelentőségének felismerése és ennek hatására a teljes mezorektum-excízió (TME) elvének megjelenése (R.J. -Bill-Heald, 1982). A 20. században a sebészet legnagyobb újítása a laparoszkópia megjelenése volt. 1990-ben történt az első laparoszkópos vastagbélmútét: Moises Jacobs végzett sikeresen jobb oldali hemikolektomiát. A laparoszkópia fejlődése a kolorektális sebészetben azóta is töretlen. Transzanális teljes mezorektum-excízió (TaTME) eljárással, kétirányú (laparoszkópos és transzanális) feltárásból a medencefenék legmélyebb területein is teljes mezorektális excízió végezhető. 2009-ben Hohenberger és társai ismertették a teljes mezokólikus excízió (Complete mesocolic excision, CME) technikáját colontumorok esetén. ${ }^{2-4} \mathrm{~A}$ robotrendszer gyors ütemủ fejlődése segíti a korábban technikailag nehezen kivitelezhető rektum műtétek elvégzését is. E technika az alsó harmadi végbélrákok ellátásában jelentene alternatívát a mai módszerekhez képest. ${ }^{5}$

A Semmelweis Egyetem I. sz. Sebészeti Klinikáján dr. Marik Miklós említendő elsőként a klinika vezető sebészei közül, mint olyan, aki rendszerezetten foglalkozott a vastagbél betegségeinek sebészi kezelésével. A vastagbél sebészetéről írt $d r$. Hedri Endre „A vastagbél sebészet problémáiról" címü írásában. A Baleseti Kórházból vele együtt érkezett a klinikára dr. Drobni Sándor, aki a vastagbélsebészet országos hírủ mestere volt a daganatsebészet és a gyulladásos vastagbélsebészet tekintetében egyaránt. 1982-ben megjelent Bélsebészet címü könyvének mintegy háromnegyede a vastagbél sebészetét taglalja, emlékeiröl előadást tartott a Magyar Coloproctologiai Társaság kongresszusán. A vastag- és végbél sebészete nem volt $d r$. Rubányi Pál és $d r$. Szécsény Andor fö érdeklődési területe, de támogatták, hogy korszerübb módszereket alkalmazzunk az aranyerek ellátásában, ideértve a Szabolcs utcában elsajátított gumigyürüs leszorítást és a Parks és Milligan-Morgan szerinti eljárásokat. Ez idő tájt, az Orvostovábbképző Intézetben $d r$. Ritter László által szervezett első tanfolyamot követően indítottunk további tanfolyamokat a sztómaterápiás nővérek képzésére, akik fontos tevékenysége ezek nyomán nyert polgárjogot - ha OKJ besorolást nem is. Javította eredményeinket a hetvenes években a korszerủ atraumatikus varróanyagok bevezetése, az egyrétegü és extramukózus varrattechnikák meghonosítása. Erröl publikált $d r$. Görög Dénes. ${ }^{6}$ Jelentős lépés volt a varrógépek bevezetése. Kezdetben a szovjet gyártmányú cserélhető fejü, többször használatos gépekkel dolgoztunk, majd megjelentek a korszerü 
gépek, melyek utódai mind a mai napig is használatosak. Ennek az időszaknak a tapasztalatairól írt disszertációt $d r$. Tóth András: „A colorectalis rák klinikumáról és sebészi kezelésének eredményeiröl”. Dr. Flautner Lajos profeszszorsága idején $d r$. Bursics Attila írt disszertációt az ultrahangvezérelt aranyérellátásról. ${ }^{7}$ A „minimálisan invazív” koncepció jegyében 1997-ben végezte $d r$. Tihanyi Tibor az első laparoszkópos vastagbélműtétet. A vastagbélrákok növekvő száma, népegészségügyi jelentősége miatt fővárosi támogatásból 2002-2003-ban kétlépcsős vastagbélrák szürést végeztünk (dr. Weltner János, $d r$. Morvai Krisztina, $d r$. Wacha Judit). Dr. Kupcsulik Péter nagy hangsúlyt helyezett a laparoszkópos vastagbélsebészet általánossá tételére, és nagyszámú mütétről számolt be különböző hazai és nemzetközi fórumokon. ${ }^{8}$ Párizsi és strasbourgi tanulmányútjainkat, majd a feltételek megteremtését követően indult útjára e módszer. Ezzel egyidejüleg vált rutinná a teljes mezorektum kiirtása is. Dr. Harsányi László támogatásával az endoszkópos sebészet fiatal ágaként $d r$. Zaránd Attila honosította meg a transzanális mütéteket (TEO), melyeket fokozatosan fejlesztünk önmagában (TAMIS) és hibrid mütétként is (TaTME). ${ }^{9}$ Ebben az időszakban nyíltak meg a végbélsebészet számára is fontos egyetemi MR-vizsgálati lehetőségek is. Dr. Szijártó Attila támogatásával a saját vizsgálati lehetőségeink is kiegészültek a transzanális/ transzrektális ultrahangvizsgálattal ( $d r$. Ónody Péter), amit elöször 1994-ben alkalmaztunk (dr. Görög Dénes) a Radiológiai Klinikával együttmüködve (dr. Jakab Zsuzsa, $d r$. Weszelits Viola, dr. Szalai Klára). Az ultrahang kitünő eszköz a hasi állapot mütét alatti és utáni követésére is, amit a sebészeink közül $d r$. Winternitz Tamás és $d r$. Zsirka-Klein Attila végez, akik a szövődmények ultrahangvezérelt diagnosztikáját és ellátását is elvégzik.

Napjainkra elértük, hogy az ileo-coecalis átmenettől az anoderáig a vastagbél minden betegségének felismerését, kivizsgálását és kezelését a kor európai színvonalán tudjuk elvégezni a végbél- és vastagbéltükrözés, az ultrahang, a nyitott és endoszkópos mütétek és a mütéti utókezelések teljes fegyvertárával. Gasztroenterológus kollégáink nap mint nap szürnek, kezelnek vastagbélbetegeket, akik egy része mütétre is kerül. A sebészeti vastag- és végbélbetegek fogadására két napon teljes rendelési időben, lehetőleg egyeztetett időpontban állunk rendelkezésre. A lehető legjobb döntés előkészítése érdekében minden vastag- és végbélbeteg esetét és minden leletét a klinika e területtel foglalkozó munkatársainak heti ülésén beszéljük meg, és itt döntünk a kezelési tervröl, továbbá folyamatosan értékeljük eredményeinket. Rosszindulatú betegség esetén ez kiegészül az onkoteam véleményének kikérésével is. Mindezek mellett az eddig elért eredmény nem jelenti azt, hogy nincs helye a további fejlödésének, melyre hagyományaink is köteleznek. A jelentős ambuláns betegforgalom mellett, évente 600-800 kolorektális mütétet végzünk klinikánkon. Ennek nagy részét tumoros folyamatok miatt. Mütéteink jelentős részét laparoszkópos technikával végezzük, onkológiai elveknek (CME, TME) megfelelően. A kolorektális betegek perioperatív kezelésében jelentős változást jelent, hogy a kivizsgálásra - ideértve a javallat megfogalmazását, a konzíliumokat és a team döntését is - a klinikai felvétel előtt kerül sor, és a beteget a mütét előtti napon vesszük fel fekvőbetegként. Ennek célja a kórházi fertőzések visszaszorítása és a költségcsökkentés. Hasonlóképpen jelentősen rövidült a mütét utáni klinikai tartózkodás ideje is. Ez elősegíti, hogy a területi és regionális ellátási igényeknek továbbra is megfeleljünk annak ellenére, hogy növekszik a vastagbélbetegségek sebészeti ellátása iránti igény.

2019. évi tevékenységünk a fő diagnózisok szerint 1483 proktológiai ellátást és 505 vastag- és vékonybélrák-ellátást jelent. Részletesen:

1. táblázat.

\begin{tabular}{llrrr}
\hline BNO kód & BNO megnevezés & Fekvő & Járó & Összesen \\
\hline I8400 & Belső, rögösödött aranyerek & 1 & 25 & 26 \\
I8410 & Belső aranyerek, egyéb szövődményekkel & 3 & 132 & 135 \\
I8420 & Belső aranyerek, szövődmény nélkül & 3 & 47 & 50 \\
I8430 & Külső, rögösödött aranyerek & & 95 & 136 \\
I8440 & Külső aranyerek egyéb szövődményekkel & 10 & 126 & 74 \\
I8450 & Külső aranyerek szövődmény nélkül & 1 & 73 & 3 \\
I8460 & Maradvány aranyeres bőrfüggelékek & & 3 & 32 \\
I8470 & Thrombotisált aranyerek, k.m.n. & & 32 & 7 \\
I8480 & K.m.n. aranyerek egyéb szövődményekkel & 17 & 334 & 351 \\
I8490 & Aranyerek, szövődmény nélkül, k.m.n. & 1 & 44 & 45 \\
K6000 & Akut végbélnýllás fissura & 6 & 128 & 134 \\
K6010 & Krónikus végbélnyílás fissura & & 100 & 100 \\
K6020 & Fissura ani k.m.n. & 13 & 155 & 168 \\
K6030 & Végbélnyílás-sipoly & 11 & 86 & 97 \\
K6040 & Végbélsipoly & & & \\
\hline
\end{tabular}


1. táblázat. (folyt.)

\begin{tabular}{|c|c|c|c|c|}
\hline BNO kód & BNO megnevezés & Fekvő & Járó & Összesen \\
\hline \multirow[t]{2}{*}{ K6050 } & Anorectalis sipoly & 5 & 25 & 30 \\
\hline & Proktológia & 71 & 1412 & 1483 \\
\hline $\mathrm{C} 1800$ & Vakbél (coecum) rosszindulatú daganata & 22 & & 22 \\
\hline $\mathrm{C} 1820$ & Colon ascendens rosszindulatú daganata & 14 & & 14 \\
\hline $\mathrm{C} 1830$ & Flexura hepatica rosszindulatú daganata & 13 & & 13 \\
\hline C1840 & Colon transversum rosszindulatú daganata & 13 & & 13 \\
\hline $\mathrm{C} 1850$ & Flexura lienalis rosszindulatú daganata & 6 & & 6 \\
\hline $\mathrm{C} 1860$ & Colon descendens rosszindulatú daganata & 4 & & 4 \\
\hline $\mathrm{C} 1870$ & Colon sigmoideum rosszindulatú daganata & 24 & & 24 \\
\hline $\mathrm{C} 1880$ & A vastagbél átfedő elváltozása, rosszindulatú daganata & 157 & & 157 \\
\hline $\mathrm{C} 1890$ & Vastagbél rosszindulatú daganata, k.m.n. & 37 & & 37 \\
\hline C19H0 & A sigmabél-végbél határ rosszindulatú daganata & 39 & & 39 \\
\hline С20HO & A végbél rosszindulatú daganata & 170 & & 170 \\
\hline $\mathbf{C 2 1 0 0}$ & Végbélnyílás rosszindulatú daganata, k.m.n. & 5 & & 5 \\
\hline \multirow[t]{3}{*}{$\mathrm{C} 2180$} & Rectum, anus és canalis analis átfedő elváltozása & 1 & & 1 \\
\hline & Vastag- és végbélrák & 505 & & 505 \\
\hline & Koloproktológia összesen & 576 & 1412 & 1988 \\
\hline
\end{tabular}

\section{Gyulladásos bélbetegségben szenvedő betegek komplex kezelése az I. sz. Sebészeti Klinikán}

A gyulladásos bélbetegségek (IBD), mint a Crohn-betegség és a colitis ulcerosa, a modern világban jelentős társadalmi, gazdasági és egészségügyi terhet jelentenek. A betegség világszerte 6-7 millió, Magyarországon mintegy $40000 \mathrm{em}-$ bert érint, elsősorban fiatal, munkaképes, családalapításra készülő embereket. ${ }^{10} \mathrm{Az}$ IBD-s beteg kezelését és gondozását vezető gasztroenterológus mellett a kezelő team elengedhetetlen tagja a sebész. ${ }^{11,12}$ Ugyan kuratív sebészi beavatkozásról (hacsak a proktokolektómiát colitis esetén nem tekintjük annak) gyakorlatilag nem beszélhetünk, IBD esetében a szövődmények elhárítását célzó mütétek a terápiás fegyvertár részeit képezik, illetve sok esetben életminöséget javító beavatkozásokról lehet szó. Az új gyógyszerek, biológiai terápia mellett a sebészi beavatkozások szükségességének aránya csökkent, azonban az esetszám-növekedés kompenzáló hatása miatt a sebészi beavatkozások száma nem lett kevesebb. A gasztroenterológuson és a sebészen kívül számos egyéb szakember tudása és munkája szükséges az IBD optimális ellátásához. ${ }^{10}$ Ezek közé tartozik a biológiai kezelésekben jártas IBD nővér, a dietetikus, a táplálásterapeuta, a radiológus, a pszichológus, a gyógytornász és a sztómaterápiás nővér is. A Semmelweis Egyetem I. és korábbi II. sz. Belgyógyászati Klinikáin jelentős hagyománya van az IBD-s betegek konzervatív gasztroenterológiai kezelésének. Ezekben az intézményekben lehetöség volt a modern biológiai kezelések korai alkalmazására, illetve preklinikai fázisú gyógyszervizsgálatok kivitelezésére.
A klinikai kutatásokat más hazai egyetemekkel közösen végezve számos közlemény jelent meg a Semmelweis Egyetem egyes szakembereinek tollából. A betegségcsoport ellátása azonban kevésbé volt centralizált a közelmúltig. Crohn, Ginsburg és Oppenheimer 1938-ban írták le a kórképet nem elsajtosodó granulomákkal, ileitis terminalisként említve. Az 50-es években Brooke és Lockhart-Mummery vezették be az ileostomia ma általános módját és formáját. A 70-es évek végén került leírásra a mára colitis ulcerosa sebészetében standard eljárássá vált, proktokolektómiát követően a bélhuzam rekonstrukcióját lehetővé tevő, ileal pouch-analis anastomosis. A szakemberek egyetemen belüli és kívüli mozgásával az utóbbi években a Külső Klinikai Tömbbe koncentrálódott az egyetemen gondozott IBD-s betegek többsége. Ehhez nagyban hozzájárult az is, hogy az I. sz. Sebészeti Klinika deklaráltan szívesen fogadja ezt a betegcsoportot, számos kolléga a szaktudását ebben az irányban fejlesztette és fejleszti, gyüjti a hazai és a külföldi tapasztalatokat is. 2016-ban, az I. sz. Belgyógyászati Klinikán a gasztroenterológiai részleg vezetöje, Dr. Lakatos Péter László segítségével Ferreira Gábor kollégánknak lehetősége nyílt, hogy egy pár hónapos tanulmányút keretében az UZ Leuven IBD- és kolorektális sebészeti centrumában szerezzen tapasztalatot. Ez a világ élvonalába tartozó gasztroenterológiai centrum, illetve az itt szerzett tapasztalatok csakúgy, mint a növekvő betegellátási igény, inspirálólag hatottak klinikánk IBD-sebészettel foglalkozó csapatára. Az IBD-sebészet fejlődése a laparoszkópia bevezetését követően új lendületet nyert. Egyre nő a laparoszkópos, illetve az elektív beavatkozások száma. A nem komplikált eseteket gyakorlatilag mind laparoszkóppal operáljuk, komplex esetekben pedig, a minél kisebb hasfali metszés érdekében, 
a mütét egy részét laparoszkóppal végezzük. Klinikánkon a gyulladásos bélbetegségek diagnosztikájának, gasztroenterológiai, illetve sebészi kezelésének vannak egyéni hagyományai. Azonban eszközparkunk (flexibilis endoszkópia, rektoszkópia), illetve infrastruktúránk a közelmúltig olyannyira amortizált és hiányos volt, hogy annak fejlesztése feltétlenül szükségessé vált. Ezáltal számos beavatkozás elvégezhetővé vált egynapos, illetve ambuláns keretek között, ugyanakkor a betegek kímélése, pszichés terhelésének csökkentése érdekében ezeket, a mütői és aneszteziológiai kapacitás növekedése mellett, rövid narkózisban, mütői körülmények között végezzük. Az országban harmadik centrumként, a Szegedi Tudományegyetem Sebészeti Klinikája és a Magyar Honvédség Egészségügyi Központ II. Sebészeti Osztálya mellett, lehetőség nyílik a perianalis fisztuláktól szenvedő Crohn-betegek zsír eredetủ allogén össejt kezelésére. Az IBD-s betegek sebészeti ellátásához, kezeléséhez speciális szemlélet és technikai-szakmai felkészültség szükséges. Bizonyos speciális mütéttípusok bevezetése folyamatban van, egyéni (ön)képzéssel, tervezéssel, protokollok kialakításával és az eredmények kritikus elemzésével. A mütéti repertoár a perianalis tályog feltárásától, laza seton drainek behelyezésétöl a laparoszkópos terminalis ileum resection, illetve vékonybél rezekción, colitis ulcerosa esetén proktokolectómián át a multiviszcerális rezekciókig terjed, nem utolsósorban véve a bélvesztés elkerülése érdekében végzett többszörös stricuroplasticákat. A korábbi hagyományok és az egyetemi személyi és szervezeti egységek átalakulásának köszönhetően az I. sz. Sebészeti Klinikán 2018 szeptemberétől olyan integrált IBD csapatmunkára nyílt lehetőség, amely gyors felzárkózást biztosíthat a nyugat-európai centrumok szakmai munkájához. Jól mutatja az együttmüködés hatását, hogy míg Klinikánkon 2010ben 33 beteg esetén 36 mütétet, 2015-ben 33 Crohn-beteg esetében 44 mütétet, 2018-ban már 43 Crohn-beteg 49 mütétjét, 2019-ben pedig 58 Crohn-beteg 64 mütétjét végeztük. Az IBD-specifikus belgyógyászati-gasztroenterológiai jelenlét és a sebészeti elkötelezettség erősödése lehetővé tette az I. sz. Sebészeti Klinikán az IBD multidiszciplináris team (IBD-MDT) megalakulását és rendszeres munkáját. A korábban szórványos IBD-MDT ülések kétheti rendszerességűvé váltak, a csapatmunkába az összes szükséges szakembert be tudtuk vonni. Az I. sz. Gyermekgyógyászati Klinika kamaszodó és felnőtté váló betegei számára havonta egy alkalommal közös tranzíciós viziteket végzünk, de egyes bonyolultabb eseteket mind belgyógyászati, mind sebészeti szempontból konzultálunk, esetenként közösen végzünk endoszkópos vizsgálatokat. A tranzíció során felmerülő klinikai kutatási kérdésekben is együttmüködünk. A táplálásterápiában jártas orvos és nővér bevonásával újabb szintet léptünk, és már az otthoni parenterális táplálás sebészi és gasztroenterológiai feladatait is egy intézményen belül el tudjuk látni. Az egyetemi ellátórendszer átszervezésével 2020 őszétől a klinikán a gasztroenterológiai ellátás tovább bővül. A csaknem 15 orvosra bővülő csapatban invazív epeúti endoszkópiában jártas kollégák, nagy tapasztalatú hepatológusok és IBD-specialisták dolgozhat- nak majd együtt egy megújult gasztroenterológiai osztályon és egy új, a modern kor minden igényét kielégítő endoszkópos laborban. Az új egységben új IBD centrum, biológiai terápiás szoba is épül.

\section{Transzanális mikrosebészet az I. sz. Sebészeti Klinikán}

Az első írásos dokumentum valódi transzanális beavatkozásról Amboise Paré (1510-1590) nevéhez kötődik, aki sikeresen kezelt szigma volvulust rektumba helyezett tubuson keresztül. Jacques Lisfranc (1790-1847) 1830-ban elsőként távolított el - legnagyobb részt transzanális behatolásból - végbéldaganatot. Verneuil transzcoccygeális végbél reszekciója (1873), majd a Kocher által kidolgozott, az os coccygeum és a szakrum részleges reszekciójával végzett rektum reszekció kevésbé vált elterjedté. A végbél alsó harmadában elhelyezkedő elváltozások eltávolítására kiváló technikának bizonyult a különbözö feltárók segítségével végzett transzanális excízió (TAE), melyet még jelenleg is sok helyen alkalmaznak. Végbélpolip ilyen módon történt eltávolításának első közlése Parks nevéhez füződik (1966). A rektum középső és felső harmadában lévő tumorok végbélnyíláson keresztül kevésbé voltak elérhetőek. Kraschke 1884-ben bemutatott módszere - poszterior proktektómia - a múlt század közepéig a rektumsebészetben az egyik legelterjedtebb sebészeti technikának számított. A beavatkozások során a kereszt- és farokcsont részleges reszekciójával, „hátulról” történt a mütét. A végbél YorkMason-féle transzszfinkterikus megközelítését szintén viszonylag gyakran alkalmazták (első hivatalos közlése 1970ből származik). A fenti lokális excíziós technikák azonban súlyos posztoperatív szövődményekkel jártak: nagy számban alakultak ki szterkorális fisztulák, illetve széklet-inkontinencia. Ezen súlyos szövődmények kiküszöbölése céljából, a Wolf céggel karöltve, Gerhard Buess kifejlesztette a transzanális endoszkópos mikrosebészeti technikát (TEM, 1984). Ez tekinthető az első valódi NOTES technikának. A TEM-mütétet eredetileg a rektum középső és felső harmadában lévő tumorok eltávolítására alkalmazták, azonban számtalan összehasonlító tanulmány alapján ma már az alsó harmadi elváltozások eltávolításában is - a jobb feltárás és vizualizáció miatt - ez a technika a legmegfelelőbb (en bloc reszekciók száma, negatív reszekciós szél). A transzanális, minimálisan invazív technika az utóbbi évtizedekben reneszánszát éli. Ennek tükrében a Storz cég is kifejlesztett egy merev rektoszkópos operációs rendszert, melyet transzanális endoszkópos operációnak (TEO) neveztek el. Még napjainkban is elsősorban ezt a két merev operációs rektoszkópot használják a rektumsebészetben. Versenytársként 2010-ben a single incision laparoscopic surgery (SILS) és a TEM-mütét „házasításával” megjelent a TAMIS (TransAnal Minimally Invasive Surgery), mely során az addig a hasi sebészetben alkalmazott egyszer használatos szilikonportot helyezték az ánuszon keresztül a rektumba, és ezen az „operációs proktoszkópon” keresztül végezték a mütétet. 
A technika 360 fokos látóteret biztosít, ezért nem szükséges a betegek mütét elött történő forgatása (pozicionálása), hagyományos laparoszkópos eszközökkel végezhető, ugyanakkor asszisztens jelenléte is szükséges a kamera és a port rögzítéséhez. A technika egyszerüsége miatt több gyártó is készít hasonló platformokat (GelPOINT path), sőt megjelentek az ún. hibrid platformok is (B-port, D-port). Több publikáció megjelent már robotasszisztált transzanális mütétek eredményeiröl is.

Magyarországon Nagy Attila professzor honosította meg az eljárást a 90-es évek elejétől. Nagy professzor a TEM-eszközt használta. Klinikánkon 2013-ban, az országban másodikként kezdtük el a transzanális endoszkópos sebészetet, a TEO eszközparkkal. ${ }^{13}$ Eddig összesen 456 betegnél végeztünk TEO-mütétet, évente mintegy $60-80$ merev rektoszkópos mütétet végzünk, de operálunk betegeket különböző TAMIS platformokkal is. A transzanális endoszkópos sebészettel kapcsolatos eredményeinket, tapasztalatainkat mintegy 30 előadásban ismertettük. Részt vettünk a transzanális mütéti útmutató kidolgozásában is. ${ }^{14} \mathrm{Az}$ elkövetkező években a transzanális technika további fejlesztését tervezzük, egy-egy kezdeti mütét után szeretnénk rutinszerüen meghonosítani a transzanális TME-t (taTME) is.

\section{Proktológiai tevékenység az I. sz. Sebészeti Klinikán}

A proktológiai kórképek az emberiséggel egyidős és a történelem talán legrégebben jegyzett betegségei közé tartoznak. Az írott történelem legkorábbi feljegyzései is említést tesznek különböző proktológiai kórképekröl. Hammurapi Kódexe Kr. e. 2200 körül például elóírja a 221. törvényében, hogy a betegnek öt sékel ezüsttel kell fizetnie az orvosának, aki a törött csontját vagy bélbaját vagy sebét meggyógyítja. A rektum prolapszus első említése pedig talán a Krónikák második könyve 21. fejezetéből ered, ahol Illés próféta megjósolta Jórám bünét és vesztét is: „Te pedig súlyos betegségbe, bélbajba esel, annyira, hogy betegséged miatt minden nap kijön a beled"; a jóslat egyébként beteljesedett. A fentieknél talán közismertebb a ma már keveset végzett Hippokratész-féle mütét anális sipolyok kezelésére. Szintén ismeretes, hogy maga XIV. Lajos is anális sipolytól szenvedett, akit 1686. november 18-án egy Charles-François Félix nevű sebész hosszas előzetes „próbamütéteket” követően megoperált, sikerrel. Sajátságos módon az elöbb említett „királyi” beavatkozás hozta meg aztán később a sebészeknek a nagyobb társadalmi megbecsülést, illetve azt, hogy nem sokkal később, 1731-ben megalakult Franciaországban az első királyi sebészeti akadémia (Academie Royale de Chiurgie). A proktológia történelme és fejlődése tehát az ókortól a középkoron és reneszánszon át egészen napjainkig végigkövethető, és bár technikai és diagnosztikai fejlődése látványos, mégis talán ezen a területen lehet találkozni a leggyakrabban a helytelen diagnózisokkal vagy a nem megfelelően megválasztott mütéti beavatkozásokkal és azok szövődményeivel. Klinikánkon évente kb. 150 proktológiai mütétet végzünk, melyek között az aranyérmütétektől a különböző komplex sipolymütéteken át a végbélprolapszusig széles palettán mozognak a beavatkozások. Klinikánk a proktológiai kutatásban mind hazai, mind nemzetközi kollaborációban is részt vesz. Örvendetes tény, hogy a proktológiai diagnosztikához a legújabb eszközök állnak rendelkezésre, illetve az országosan is nagyon szórványosan elérhető anális/rektális ultrahangvizsgálat végzésére is van lehetőség. Az ultrahang segítségével olyan költségesebb vagy nehezebben kivitelezhető radiológiai modalitások lettek részben kiválthatók, mint a rektális MRI vagy például a hagyományos fisztulográfia. ${ }^{15,16} \mathrm{~A}$ konvex ultrahang-vizsgálófejjel pedig rektokele, enterokele vagy defekációs disszinergia is könnyedén vizsgálható. Az ultrahang nemcsak a proktológiai elváltozásokban, de alsó harmadi rektumdaganatok utánkövetésében és stagingvizsgálatában is sokszor hasznos segítséget nyújt. A mütéti beavatkozások a korábbi hagyományokra épülő mütéteket nem mellőzve újabb lendületet kaptak. Az aranyérmütétek kapcsán jó tapasztalatokat szereztünk a HAL-RAR ${ }^{\odot}$ beavatkozásokkal, illetve a sipolymütétekkel kapcsolatban is egyre bővülnek a lehetőségeink. Az országban elsőként került bevezetésre a sipolymütéteknél könnyedén használható FiXcision ${ }^{\mathbb{O}}$ eszköz, melynek eredményeiröl a Magyar Sebésztársaság Coloproctológiai és Endoszkópos Szekciójának 2019. évi Kongresszusán számoltunk be. ${ }^{17}$ Összesen 15 beteget operáltunk Parks-2 típusú sipollyal, 10 betegünk az első beavatkozást követően primeren gyógyult, míg 5 betegünknél újabb műtétre volt szükség, a $66 \%$-os primer sikerarány a nemzetközi irodalomban fellelhető eredményekkel összevethető, a nemzetközi átlagot mutatta. A Semmelweis Egyetem II. sz. Sebészeti Klinikával együttesen veszünk részt egy új proktológiai eszközfejlesztésben $\left(\mathrm{BioHealx}^{\odot}\right)$, melynek ígéretes állatkísérletes eredményei után egyetemünkön került elsőként humán bevezetésre és kipróbálásra. Szoros kollaborációban dolgozunk egyetemünk Börgyógyászati Klinikájával. Az STD ambulancián megjelenő betegeket soron kívül fogadjuk, illetve a proktológiai rendelésen megjelenő betegek STD kórokozók molekuláris biológiai (PCR) vizsgálatára már helyben is van lehetőségünk. Távlati célunk, hogy országosan elsőként egyetemünkön megalakulhasson egy kismedencei sebészeti centrum nőgyógyász, urológus, radiológus, ideggyógyász, fizioterapeuta és proktológus-sebész bevonásával. A centrumban kismedencei fájdalomszindrómák, különböző vizelet- és széklet-inkontinenciák, szülési sérülések, prolapszusok komplex sebészi és nem sebészeti kezelését tüztük ki célul. Az első lépéseket megtettük, az alapító okiratot az egyetem befogadta. Különböző képalkotó vizsgálatok felélesztése (hagyományos defekográfia) és újabbak elindítása (MRI defekográfia, EMG-biofeedback-vizsgálat), valamint újabb kollaborációk és új sebészeti eljárások kiépítése és elindítása az Idegsebészeti Tanszékkel (Sacralis Neuro Stimuláció - SNS) pedig folyamatban vannak. 


\section{Irodalomjegyzék}

${ }^{1}$ Bosetti C, Levi F, Rosato V, Bertuccio P, Lucchini F, Negri E, La Vechia: Recent trends in colorectal cancer mortality in Europe. Int J Cancer 2011; 129: 180-191.

${ }^{2}$ Warren EE: The Natural History of Rectal Cancer 1908 2008: The Evolving Treatment of Rectal Cancer into the Twenty-First Century. Seminars in Colon and Rectal Surgery $2010 ; 21: 56-74$.

3 Galler AS, Petrelli NJ, Shakamuri SP: Rectal cancer surgery: a brief history. Surg Oncol 2011; 20: 223-230.

4 Inoue Y, Kusunoki M: Resection of rectal cancer: a historical review. Surg Today 2010; 40: 501-506.

${ }^{5}$ Park EJ, Baik SH: Robotic Surgery for Colon and Rectal Cancer. Curr Oncol Rep 2016; 18: 5.

${ }^{6}$ Görög D, Péter A, Szabó J, Perner F: Single-layer continuous suturing for end-to-end colonic anastomosis using a modified closed-bowel technique. Surg Today 2004; 34: 642-644.

${ }^{7}$ Bursics A, Weltner J, Flautner L: Doppler-vezérelt artéria haemorrhoidális ligatúra : minimálisan invazív módszer az aranyeresség kezelésére. Endoscopia és Minimálisan Invazív Terápia 2001; 4: 27-29.

${ }^{8}$ Kupcsulik P, Tamás J, Pálházy T, Lukovich P, Weltner J: Laparoscopos colorectalis resectiók - 393 eset tapasztalatai. [Laparoscopic colorectal resections - experience based on 393 cases]. Magy Seb 2013; 66: 138-145.

${ }^{9}$ Zaránd A: TEO: Minimálisan invazív rectumsebészet. Rövid áttekintés. [TEO: minimally invasive surgery of the rectum. A short review]. Magy Seb 2014; 67: 15-17.

${ }^{10}$ GBD 2017 Inflammatory Bowel Disease Collaborators: The global, regional, and national burden of inflammatory bowel disease in 195 countries and territories, 19902017: a systematic analysis for the Global Burden of Disease Study 2017. Lancet Gastroenterol Hepatol 2020; 5: 17-30.

${ }^{11}$ Golovics PA, Lakatos L, Mandel MD, Lovasz BD, Vegh Z, Kurti Z, Szita I, Kiss LS, Pandur T, Lakatos PL: Pre- valence and predictors of hospitalization in Crohn's disease in a prospective population-based inception cohort from 2000-2012. World J Gastroenterol 2015; 21: 7272-80.

${ }^{12}$ Kürti Zsuzsanna: A gyulladásos bélbetegségek elöfordulása és kezelésének jellemzői országos felmérés alapján, valamint a kezelések lehetséges szövődményei. PhD-értekezés, 2018.

13 Ács B, Szász AM, Kulka J, Harsányi L, Zaránd A: Kellően radikális? Transanalis endoscopos mikrosebészeti technika szerepe a rectum daganatainak ellátásában egy év tapasztalatainak klinikopatológiai értékelése. [Is it radical enough? Transanal endoscopic microsurgery for the treatment of rectal neoplasia - clinicopathological viewpoint]. Magy Seb 2014; 67: 329-333.

14 Almási K, Ábrahám S, Baracs J, Bursics A, Jánó Z, Sztipits T, Szüts Á, Tóth D, Zaránd A, Bánky B: Transzanális mütéti útmutató. [Guidance for transanal operations]. Magy Seb 2019; 72: 33-46.

${ }^{15}$ Brillantino A, Iacobellis $F$, Reginelli A, Monaco L, Sodano B, Tufano $G$, Tufano A, Maglio M, De Palma M, Di Martino N, Renzi A, Grassi R: Preoperative assessment of simple and complex anorectal fistulas: Tridimensional endoanal ultrasound? Magnetic resonance? Both? Radiol Med 2019; 124: 339-349.

16 Siddiqui MR, Ashrafian H, Tozer P, Daulatzai N, Burling $D$, Hart A, Athanasiou T, Phillips RK: A diagnostic accuracy meta-analysis of endoanal ultrasound and MRI for perianal fistula assessment. Dis Colon Rectum 2012; 55: 576-85.

${ }^{17}$ Kasiri MM, Riss S, Stift A, Binder AD, Kogovšek $U$, Huth $M$, Kronberger IE: Optimized fistulectomy using the novel FiXcision ${ }^{\circledR}$ device: a technical feasibility study and evaluation of short term healing rates. Tech Coloproctol 2019; 23: 579-582.

A cikk a Creative Commons Attribution 4.0 International License (https://creativecommons.org/licenses/by/4.0/) feltételei szerint publikált Open Access közlemény, melynek szellemében a cikk bármilyen médiumban szabadon felhasználható, megosztható és újraközölhetö, feltéve, hogy az eredeti szerző és a közlés helye, illetve a CC License linkje és az esetlegesen végrehajtott módosítások feltüntetésre kerülnek. (SID_1) 